Cochran, M., Peacock, M., Smith, D. A., and Nordin, B. E. C. (1968). British Medical fournal, 2, 721 .

Frost, H. M. (1967). In L'Ostéomalacie, edited by D. J. Hioco, p. 3. Paris, Masson.

Garner, A., and Ball, J. (1968). Fournal of Pathology and Bacteriology, 91, 545.

Holt, L. E., jun., La Mer, V. K., and Chown, H. B. (1925). fournal of Biological Chemistry, 64, 509.

Joplin, G. F., Robinson, C. J., Melvin, K. E. W., Thompson, G. R., and Fraser, R. (1967). In L'Ostéomalacie, edited by D. J. Hioco, p. 249. Paris, Masson.

Knowles, F. (1968). Fournal of Medical Laboratory Technology, 25, 130. Lemann, J., jun., Litzow, J. R., and Lennon, E. J. (1967). Fournal of Clinical Investigation, 46, 1318.

Litzow, J. R., Lemann, J., jun., and Lennon, E. J. (1967). Fournal of Clinical Investigation, 46, 280.

Miravet, L., Hioco, D., and Ryckewaert, A. (1967). In L'Ostéomalacie, edited by D. J. Hioco, p. 285. Paris, Masson.

Morgan, D. B., Stanley, J., and Fourman, P. (1968). Clinical Science, 35, 337 .
Nordin, B. E. C. (1959). British fournal of Urology, 31, 404

Nordin, B. E. C., and Bulusu, L. (1968). Postgraduate Medical fournal, 44, 93.

Nordin, B. E. C., and Smith, D. A. (1965). In Diagnostic Procedure in Disorders of Calcium Metabolism. London, Churchill.

Nordin, B. E. C., and Smith, D. A. (1967). In L'Ostéomalacie, edited by $D$ J. Hioco, D. 379. Paris, Masson.

Peacock, M. Knowles, F., and Nordin, B. E. C. (1968). British Medical Fournal, 2,729 .

Pellegrino, E. D., and Biltz, R. M. (1965). Medicine (Baltimore), 44, 397.

Stanbury, S. W. (1967). In Renal Disease, 2nd ed., edited by D. A. K. Black, p. 665. London, Oxford.

Stanbury, S. W. (1968). American Fournal of Medicine, 44, 714.

Stanbury, S. W., and Lumb, G. A. (1962). Medicine '(Baltimore), $41,1$.

Stanbury, S. W., and Lumb, G. A. (1966). Quarterly fournal of Medicine, 35, 1.

Yendt, E. R., and Howard, J. F. (1955). Bulletin of the Fohns Hopkins Hospital, 96, 101.

\title{
Effect of Propranolol on Exercise Tolerance of Patients with Atrial Fibrillation
}

\author{
R. W. BROWN, * M.B., B.S., M.R.A.C.P. ; A. J. GOBLE, $†$ M.D., F.R.A.C.P., M.R.C.P.
}

\begin{abstract}
Cummary : Six patients with atrial fibrillation who were $S$ taking digitalis were exercised before and after $30 \mathrm{mg}$. of propranolol twice daily. Though there was a lower pulsé rate at rest and on exercise in all patients, three suffered deterioration of exercise tolerance. It is concluded that propranolol does not improve the exercise tolerance of patients with atrial fibrillation whose resting ventricular rate is controlled with digitalis.
\end{abstract}

\section{Introduction}

It has been shown experimentally in animals that, under exercise conditions, increasing pulse rate is associated with increasing cardiac output up to a critical value, after which diastolic filling of the ventricles is impaired and the cardiac output falls (Corday and Irving, 1961). It is not known at what level the change occurs in human hearts in sinus rhythm, but some physiologists have suggested that it is between 160 and $180 /$ minutes (Rushmer, 1960; Wood, 1968). Ventricular rates during submaximal and maximal exercise are about $10 \%$ higher than this in patients with atrial fibrillation who are taking digitalis (Hornstein and Bruce, 1968). Propranolol, which is known to reduce the ventricular rate at rest and during exercise (Harrison et al., 1965 ; Chamberlain, 1966 ; Schulman et al., 1967), may improve the exercise tolerance of patients with atrial fibrillation via this mechanism. This improvement might outweigh the negative inotrophic action of the drug and produce a net benefit.

A double-blind trial was therefore devised to determine whether the addition of propranolol resulted in clinical improvement in the exercise tolerance of patients with atrial fibrillation taking digitalis.

* Cardiac Registrar.

t Cardiologist.

Royal Melbourne Hospital, Melbourne, Victoria, Australia.

\section{Patients and Methods}

Outpatients with chronic atrial fibrillation taking digitalis and whose general medical condition had been stable for some weeks were selected. The clinical details are shown in the Table. Five of the six had rheumatic heart disease and one was euthyroid after radiation therapy for thyrotoxicosis.

The patients continued to take their usual therapy, including digitalis, and were subjected to exercise on three occasions, each a week apart. After the first test they were allocated, by double-blind method, either propranolol $30 \mathrm{mg}$. twice daily or a placebo for the first week, and were given the alternative after the second test.

Before each exercise test the patients were interviewed, their pulse rate and arterial pressure were taken, and they were examined for signs of cardiac failure. Each patient then undertook the same three levels of exercise on a treadmill at a $5^{\circ}$ slope for three minutes. The maximum level achieved by each patient on the first test was attempted at both subsequent tests.

The heart rate and electrocardiograph were monitored throughout the test, and the heart rate over the last 30 seconds was recorded by means of a Royal Melbourne Hospital cardiac cycle counter (Mark II). The arterial pressure was taken immediately the exercise was completed.

\section{Results}

Fig. 1 illustrates the difference in heart rate at rest and on exercise with and without propranolol. In the one patient who did not actually exercise at $3 \mathrm{~km}$./hour an estimated pulse rate was determined from the line of best fit on a pulse-rate/workload graph. In all cases there was a reduction in pulse rate after propranolol, and the mean reduction of pulse rate was $28 /$ minute at rest, $39 /$ minute at $3 \mathrm{~km}$./hour, and $36 /$ minute at the maximum exercise level. 
Clinical Details of the Patient

\begin{tabular}{|c|c|c|c|c|c|c|c|}
\hline $\begin{array}{l}\text { Case } \\
\text { No. }\end{array}$ & Age & $\begin{array}{l}\text { Cardiac } \\
\text { Disease }\end{array}$ & $\begin{array}{l}\text { Functional } \\
\text { Classificationt }\end{array}$ & $\begin{array}{c}\text { Maximum Exercise } \\
\text { Level }(\mathrm{km} \text {./hour })\end{array}$ & $\begin{array}{l}\text { Maximum Pulse } \\
\text { Rate (Control) }\end{array}$ & $\begin{array}{l}\text { Patients' Observations } \\
\text { After Propranolol }\end{array}$ & $\begin{array}{l}\text { Clinical Observations } \\
\text { After Propranolol* }\end{array}$ \\
\hline 1 & 54 & R.H.D. mitral valvotomy. & Class 1 & $5 \cdot 25$ & 178 & Unchanged & Unchanged \\
\hline $\begin{array}{l}2 \\
3 \\
4\end{array}$ & $\begin{array}{l}34 \\
44 \\
48\end{array}$ & $\begin{array}{l}\text { Hypertension } \\
\text { R.H.D. M.S. M.I. } \\
\text { Controlled thyrotoxicosis } \\
\text { R.H.D. M.S. I.H.D. }\end{array}$ & $\begin{array}{l}\text { Class } 2 \\
\text { Class } 2 \\
\text { Class } 2\end{array}$ & $\begin{array}{l}5 \cdot 0 \\
6 \cdot 0 \\
4 \cdot 0\end{array}$ & $\begin{array}{l}176 \\
190 \\
184\end{array}$ & $\begin{array}{l}\text { Unchanged } \\
\text { Unchanged } \\
\text { Noted increased dyspnoea }\end{array}$ & $\begin{array}{l}\text { Unchanged } \\
\text { Unchanged } \\
\text { J.V.P. raised } 2 \mathrm{~cm} .\end{array}$ \\
\hline 5 & 55 & R.H.D. M.I. & Class 2 & $5 \cdot 0$ & 154 & Noted increased effort & $\begin{array}{l}\text { Unable to complete exercise } \\
\text { test because of dyspnoes }\end{array}$ \\
\hline 6 & 52 & R.H.D. M.I. & Class 3 & 3.5 & 128 & $\begin{array}{l}\text { Increased dyspnoea noted } \\
\text { during exercise test only }\end{array}$ & $\begin{array}{l}\text { Collapse during exercise test } \\
\text { (sec text) }\end{array}$ \\
\hline
\end{tabular}

- The changes in pulse rate and arterial pressures are set out in Figs. 1 and 2.

+ New York Heart Association.

R.H.D. = Rheumatic heart disease. M.S. = Mitral valve stenosis, M.I = Mitral valve incompetence. P.N.D. paroxysmal nocturnal dyspnoea. J.V.P. = Jugular venous pressure.

The reductions in systolic blood pressure after propranolol at the same exercise levels is shown in Fig. 2. The mean reduction at rest was $21 \mathrm{~mm}$. $\mathrm{Hg}$, at $3 \mathrm{~km}$./hour $28 \mathrm{~mm}$. Hg, and at the maximum level of exercise $39 \mathrm{~mm}$. $\mathrm{Hg}$.

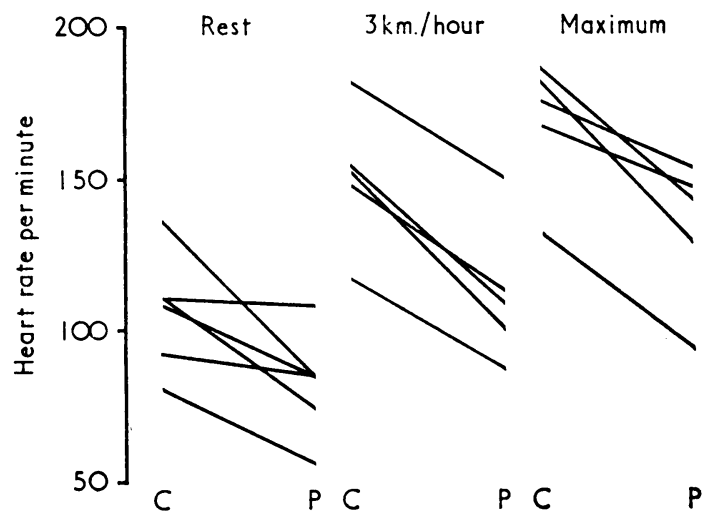

Fig. 1.-Pulse rate at rest and two exercise levels. $\mathrm{C}=$ Control (placebo). $\mathrm{P}=$ Propranolol.

Three of the six patients noted definite worsening of their esercise tolerance and all three had objective evidence of deterioration.

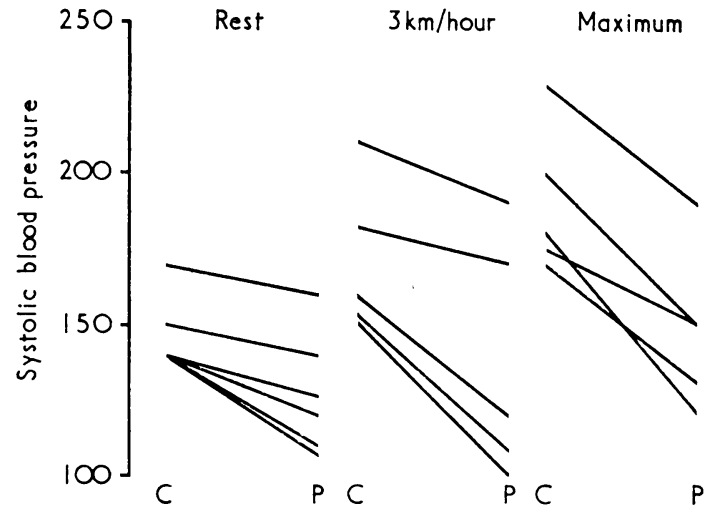

Fig. 2.-Arterial pressure at rest and two exercise levels. $\mathrm{C}=$ Control (placebo). $\mathrm{P}=$ Propranolol.

One (Case 4) reported increased dyspnoea on effort and on examination was found to have raised jugular venous pressure. $\mathrm{He}$ was able to complete the exercise test. Another (Case 5) noted increased effort dyspnoea and suffered an episode of paroxysmal nocturnal dyspnoea. He was unable to reach his previous level of exercise because of dyspnoea. He had no clinical signs of cardiac failure. The third patient (Case 6) developed a supraventricular tachycardia during the test after taking the placebo. Despite suppression of this arrhythmia by propranolol, she still noted increased dyspnoea and collapsed with severe dyspnoea, cough, and pallor at the highest exercise level. In this patient satisfactory measurements of pulse and blood pressure were not obtained at that test, and her exercising results are not included in Figs. 1 and 2.

In view of the definite clinical deterioration in three of the six patients and lack of symptomatic improvement in the others, the trial was abandoned.

\section{Discussion}

Since half the patients deteriorated clinically and none improved, it is concluded that the addition of propranolol does not improve the exercise tolerance of patients with atrial fibrillation taking digitalis at the pulse levels attained in the trial. As the rate at which tachycardia interferes with diastolic filling is not known, the patients under test may not have exceeded this level. Therefore, since cardiac output increases with increasing pulse rates up to this unknown critical level, the reduotion in pulse rate may well have been harmful. There is some evidence that this critical rate in fact may be over 200 in normal hearts and even in patients with mitral stenosio-a group in particular who should benefit from a longer diastolic period (Åstrand et al., 1963 ; Graybiel, 1964 ; Rowlands et al., 1965). The negative inotrophic action of the drug also cannot be ignored, and cases of cardiac failure attributed to the use of the drug have already been reported (Epstein and Braunwald, 1966 ; Conway et al., 1968).

The clinical deterioration in three of the six cases is consistent with the laboratory findings of Schulman et al. (1967) and of Cumming and Carr (1966), who detected a reduction in cardiac output with exercise, after administration of propranolol to patients with mitral stenosis and atrial fibrillation.

We thank Dr. Charles Proctor for his assistance in the design of the trial and for the supply of propranolol, and Mrs. Elizabeth Tronson and Miss Glenda Hoffmann, who helped with the exercise tests and the preparation of the manuscript.

\section{REFERENCRS}

Asstrand, I. Cuddy, T. E., Landegren, J., Malmborg, R. O., and Saltin, B. (1963). Acta Medica Scandinavica, 173, 121.

Chamberlain, D. A. (1966). Cardiologia, 49, Suppl. No. 2, p. 27. Conway, N., Seym

fournal, 2, 213 .
Cordav, E., and Irving, D. W. (1961). Disturbances of Heart Rate, Rhythm and Conduction. Philadelphia, Saunders.

Cumming, G. R., and Carr, W. (1966). Canadian Medical Association fournal, $95,527$.

Epstein, S. E., and Braunwald, E. (1966). Nero England fournal of Medicine, 275, 1175 .

Graybiel, A. (1964). American fournal of Cardiology, 14, 828.

Harrison, D. C., Grifin, J. R., and Fiene, T. J. (1965). New England Fournal of Medicine, 273, 410.

Hournal T. R., and Bruce, R A. (1968). Circulation, 37, 543.

Rowlands, D. J., Howitt, G., and Markman, P. (1965). British Medical fournal, 1, 891 .

Rushmer, (1960). In Medical Physiology and Biophysics, 18th ed., edited by T. C. Ruch and J. F. Fulton. Philadelphia, Saunders.

Schulman, C. L., Sulit, Y. Q. M., Leinbach, R. C., Harthorne, J. W., and Saunders, C. A. (1967). Circulation, 36, Suppl. No. 2, II,

Wood, P. (1968). Diseases of the Heart and Circulation, 3rd ed. London, Eyre and Spottiswoode. 